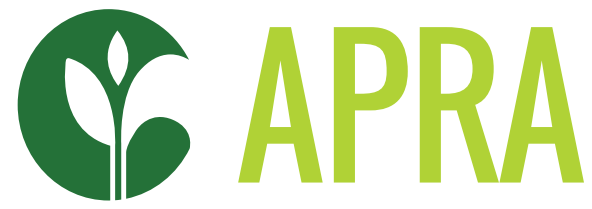

Agricultural Policy Research in Africa

\title{
COCOA COMMERCIALISATION IN NIGERIA: ISSUES AND PROSPECTS
}

Kehinde Adesina Thomas, Adeola Olajide and Molatokunbo O. Olutayo 


\section{CONTENTS}

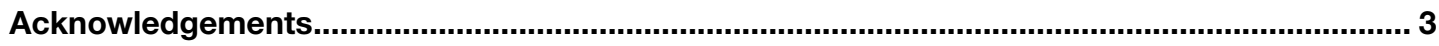

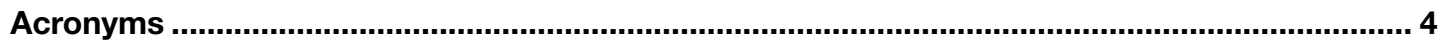

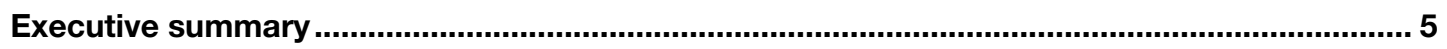

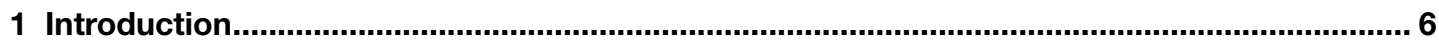

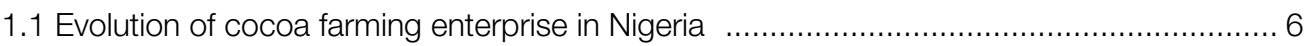

1.2 Nigeria's performance in the global cocoa production scale ........................................ 7

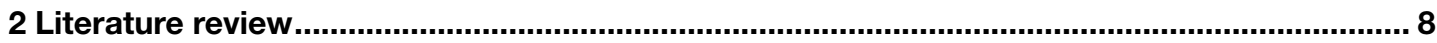

2.1 Pre- and post-independence structure of cocoa commercialisation in Nigeria................... 8

2.2 Post-independence framework of cocoa commercialisation - the marketing board ........... 9

2.3 Intricacies around the cocoa marketing board - the Nigerian experience ........................ 10

2.4 Benefits of cocoa marketing board framework......................................................... 10

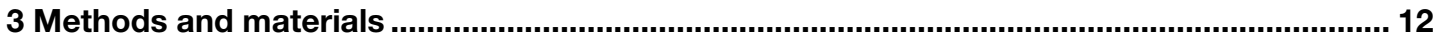

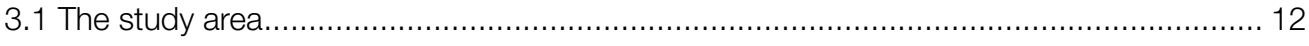

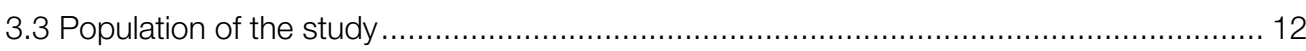

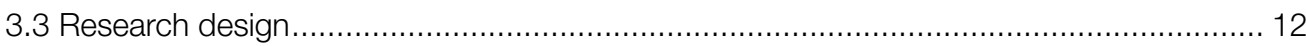

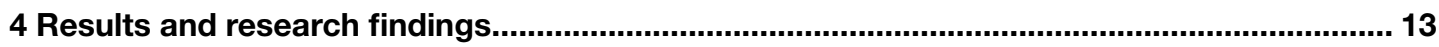

4.1 Change in economy and livelihoods among Nigerian cocoa farmers ............................. 13

4.2 Contributions of cocoa enterprise on farmers' income and poverty reduction ................. 13

4.3 Movement towards greater intensification among cocoa farmers in Nigeria..................... 14

4.4 Push and pull factors for cocoa commercialisation in Nigeria ...................................... 14

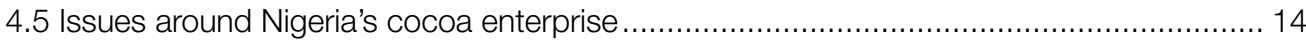

4.6 Nigeria's cocoa enterprise from a futuristic view..................................................... 18

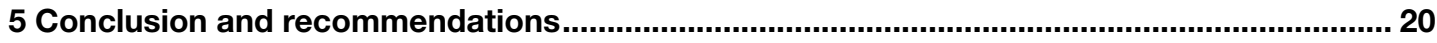

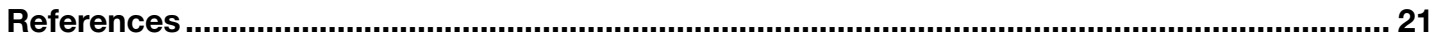

\section{List of tables}

Table 4.1: Activities carried out by women and children in cocoa enterprise......................... 15

\section{List of figures}

Figure 1.1: Top ten cocoa producing countries in 2018 (in tonnes) 


\section{ACKNOWLEDGEMENTS}

The authors are grateful to Agricultural Research Policy in Africa (APRA), International Development Studies (IDS) and the United Kingdom Government for funding and advisory support for this research work. We also appreciate all the interviewees who patiently shared their views and experiences with us.

Kehinde Adesina Thomas is a Senior Lecture in the Department of Agricultural Extension and Rural Development, University of Ibadan, Nigeria. Adeola Olajide is a Senior Lecturer in the Department of Agricultural Economics, University of Ibadan, Nigeria. Molatokunbo O. Olutayo, is a Senior Lecture in the Department of African Studies, University of Ibadan, Nigeria.

This working paper is funded with UK aid from the UK government (Foreign, Commonwealth \& Development Office - FCDO, formerly DFID). The opinions are the authors and do not necessarily reflect the views or policies of IDS or the UK government. 


\section{ACRONYMS}

CFAN

Farmers' Association of Nigeria

FGD

focus group discussion

IDI

in-depth interview

LBA

Local Buying Agent

LGA

Local Government Area

NCB

Nigerian Cocoa Board

NCDC

National Cocoa Development Committee

SAP

Structural Adjustment Programme 


\section{EXECUTIVE SUMMMARY}

Despite the setback in the Nigerian agricultural sector's development and its declining cocoa production in recent years, the nation still has potential to regain its production capacities in the cocoa sub-sector. Thus, this paper explores the issues and prospects around cocoa commercialisation in southwestern Nigeria. An exploratory and qualitative study design involving key actors along the cocoa value chain was adopted. Purposively, high, medium and low cocoa-producing states in southwestern Nigeria were selected using National Bureau of Statistics (2020) data. These included Ondo, Osun and Ogun states, respectively. Thereafter, the highest cocoa-producing Local Government Areas (LGAs) and cocoa farming households were randomly selected for interviews. The study held 32 focus group discussions (FGDs), 25 in-depth interviews (IDIs) and 15 life history interviews with famers, processors, input dealers and marketers in each state. Ethical considerations for participation and requisite experience of at least ten years in the respective value chains were considered for inclusion.
The study revealed that cocoa enterprises greatly improved the economy and livelihood status of cocoa farmers, especially in the pre- and early postindependence era. Though the marketing board era had its associated challenges, cocoa farmers fared better under it than under the liberalised cocoa market period, mainly as a result of its organised system of input and post-harvest monitoring supports. Cocoa farming intensification was, likewise, observed to have declined due to constraints such as reduction in soil fertility, limited land to establish new cocoa farms, scarcity of labour, ageing of cocoa trees, frequent disturbance from cattle herdsmen and gold mining excavators, and poor technological, infrastructural, financial and extension support. Nonetheless, cocoa farmers across their gender disaggregation opined that cocoa farming still has a bright future in the study area if attendant challenges are promptly addressed, because the interest and drive to expand production still exists among farmers. 


\section{INTRODUCTION}

\subsection{Evolution of cocoa farming enterprise in Nigeria}

Cocoa has remained the leading agricultural export crop in Nigeria for decades. Nigeria is the world's fourth largest cocoa producer and the third largest exporter after Côte d'Ivoire and Ghana (Verter and Bečvářová, 2014). During the late pre-independence and early post-independence years in Nigeria (1950s to 1970s), cocoa was a major foreign exchange earner. However, following investments in the oil sector in the 1970s and 1980s, Nigeria's share of world cocoa output declined. Some of the foremost cocoa farms in Nigeria were established around the 1870s in Bonny and Calabar, in the eastern part of the country. However, the area was later identified not to be very suitable for cocoa cultivation likely due to its soil and climatic features. In 1880, a cocoa farm was set up in Lagos, after which more cocoa farms were established in Agege and Ota axis in Lagos State, Nigeria. These regions offered favourable soil, climatic parameters and economic returns. There was then a diffusion of cocoa farming innovation from Agege and Ota axis to the Yoruba hinterland, after which adoption of cocoa farming spread to other states in western Nigeria, namely; Ekiti, Ogun, Ondo, Osun and Oyo (Williams, 2009). According to Berry (1975), farmers in Ibadan and Egba land began to trial cocoa farming by planting cocoa in uncultivated forests around 1890, while those in llesha axis started around 1896. Cocoa cultivation later extended to Okeigbo and Ondo towns, both in Ondo State and to Ife and Gbongan in Osun State, which further expanded to Ekiti land. The dominant cocoa variety in those early days of cocoa farming in Nigeria were Amelonado cacao, which was imported from the upper Amazon River Basin in Brazil, and a heterogeneous strain from Trinidad. This variety's popularity continues still today as a result of its disease resistance, tolerance to adverse climatic conditions and quality fruits.

Since the pre-independence days, the Cocoa Marketing Board was established to oversee cocoa post-harvest and marketing activities among farmers. This led to the formation of cooperative societies, through which other necessary cocoa production supports were accessed by farmers. The marketing board, as the only body empowered to regulate cocoa enterprise affairs, operated monopolistically and was later deemed inefficient after two decades of operations. Hence, in the 1980s, the World Bank and the International Monetary Fund advised Nigeria to liberalise the cocoa sub-sector. In 1986, Nigeria heeded this advice and dissolved the marketing boards to liberalise cocoa marketing and trade.

\section{Figure 1.1: Top ten cocoa-producing countries in 2018 (in tonnes)}

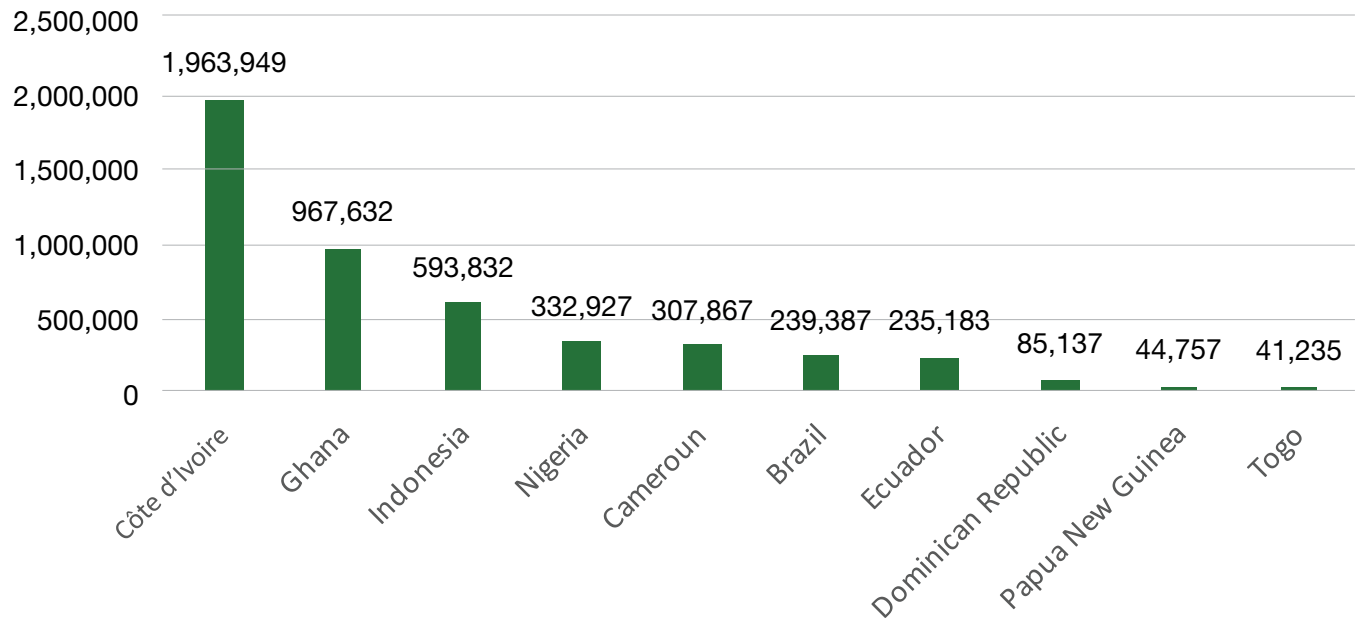


Consequently, the anticipated outcome of this action, which was fair prices for farmers and high economic returns from the government, never materialised. Rather, cocoa farmers were left with little or no support for production, and the quality of cocoa beans dropped because quality check mechanisms associated with the marketing board system were scrapped. Although the local price of cocoa beans increased, the cartel of buying agents did not allow farmers to sufficiently reap the gains of this. Furthermore, ageing cocoa trees and farms, poor yields, inconsistent production patterns, disease and pest infestation and poor agricultural mechanisation contributed to a stagnant cocoa industry in the country.

\subsection{Nigeria"s performance in the global cocoa production scale}

During the pre-independent and early independence years (1950s to the mid-1960s), the Nigerian economy largely depended upon the export of cocoa. By the mid-1950s, Nigeria had become one of the world's leading cocoa exporters, with volumes reaching around 280,000t. As a result, cocoa became the country's top foreign export crop, accounting for approximately 30 per cent of its foreign-exchange earnings (Walker, 1999). However, the cocoa boom era was short-lived due to the diversion of attention to crude oil, and since the discovery of crude oil in commercial quantities in Nigeria, the cocoa sub-sector, and by extension the agricultural sector, has been declining in performance.

According to PwC (2016), Nigeria's output in cocoa production declined by 37.9 per cent between 2010 and 2014, while other cocoa-producing countries in West Africa have recorded increases in output due to expansion in cocoa farmland area and increased use of inputs. In the last four decades, Côte d'Ivoire has remained the largest producer of cocoa beans in the world, followed by Ghana, which moved from fourth to second position in 2014. Nigeria has, however, been lagging behind and struggling to retain the fourth position in global cocoa production since 2014. Figure 1.1 shows the scale of cocoa production in the top ten cocoa-producing countries in the world. 


\subsection{Pre- and post-independence structure of cocoa commercialisation in Nigeria}

The Nigerian government's efforts to develop agriculture during the pre-independence era concentrated more on the production of cash crops, such as groundnut and cotton in the north, cocoa and coffee in the west, and oil palm and rubber in the east. This was partly to satisfy the demands of the British for cheap sources of raw materials to be exported for their industrial growth. On their arrival to Nigeria during the $19^{\text {th }}$ century, the British met an agricultural economy which was self- sufficient in food and produced several export commodities.

Nevertheless, the mild food scarcity of 1960 to 1970 pushed the government to concentrate briefly on food production. This was evidenced in the Planned Expenditure of 1962 to 1968 when 9.8 per cent of the total government budget was allocated to the agricultural sector. Between 1970 and 1982, agricultural growth stagnated at less than 1 per cent, with a sharp decline in the production of export crops. Similarly, per capita caloric food supply declined from surpluses in the 1960s to a deficit of 38 per cent in 1982 when Nigeria became a net importer of vegetable oil, meat, dairy products, fish and grains - notably rice wheat and maize - with food import bills rising astronomically (FMA, 1984). The factors responsible for this trend in agricultural growth of the economy were identified by FMA (1984) and grouped under two major classes: demand-side factors and production-side factors.

On the demand side, the primary contributing factors were the high rates of population growth, per capita real income, and urbanisation stemming from a high rate of rural urban migration. During this period, the economy recorded an urban population growth rate of 4.7 per cent per annum compared to 1.95 per cent per annum in the rural areas (FMA, 1984). On the other hand, the production side had many fundamental problems from farm resource constraints, especially labour and capital availability, poor production technology, poor storage, poorly developed marketing systems and the past neglect of agriculture in developmental planning. Consequently, to surmount the aforementioned problems, the government rolled out a plan of action made up of policies designed to stimulate the growth and development of agriculture to positively impact on the overall growth of the Nigerian economy. This included such policies as the restructuring of the marketing board system for export crops and the creation of marketing boards for grains and root crops. These and subsequent policies also had broad components for implementation amongst the government ministries, department units and private sector.

Generally, agricultural policies in Nigeria have undergone four key phases since independence. The first from 1960 to 1969; second from 1970 to 1979, the period of the oil boom; third from 1980 to the late 1990s, during the Structural Adjustment Programme (SAP); and lastly, the National Economic Empowerment and Development Strategy framework (Prabuddha and Babu, 2010). According to FMA (1989), the purpose of agricultural policy was to develop favourable and sustainable guidelines for the promotion of efficient agricultural practices that will guarantee food security, provide employment for citizens and raw materials for all agrobased industries, and earn foreign exchange. Uniquely, it was the synthesis of the framework and action plans of the government designed to achieve overall agricultural growth and development. Due to the insufficiencies of these programmes and policies to totally address and provide solutions to these issues, more measures have been continually developed to tackle these issues since the nation gained her independence.

To this end, programmes and policies introduced after independence were aimed at rural development through the improvement of the rural agricultural sector. These programmes and policies included the Plantation and Farm Settlement scheme in 1960, Operation Feed the Nation in 1976, and Agricultural Insurance in 1984, and up until the present day, many other programmes have been designed and used. While some of these measures had positive outcomes, there were still loopholes and gaps left out. The major issues have always centred on poor administration, poor community entry as a result of inefficient sensitisation and mobilisation, the top-down approach of most of the programmes, and fund mismanagement. 
Hence, commercial reorientation of agricultural production, which occurs for primary staple cereals as well as for the so-called high-value cash crops such as cocoa and cotton, remains important. Alternatively, commercialisation implies that both traded and nontraded inputs are rated in terms of their market value. As a result, commercialisation of agricultural systems leads to greater market orientation of farm production; progressive substitution out of non-traded inputs in favour of purchased inputs; and the gradual decline of combined farming systems.

Therefore, handling agriculture as a business other than a subsistent way of life, with managerial steps to improving agricultural growth in the rural settings, became important both for staple food crops and cash crops in the $19^{\text {th }}$ century. One of the important ways through which such businesses pitched to promote agro-economic growth was by output commercialisation, which helps to integrate farmers from subsistent-oriented ventures into the cash economy (Woldeyohanes, Heckelei and Surry, 2015). Hence, agricultural commercialisation had the potential of addressing the challenges associated with malnutrition, unemployment and poverty in the rural community (Ibrahim, 2016). Nevertheless, low quantities of marketable surpluses affect farmers' competitiveness to commercialisation of crops. Inadequate access to improved production inputs decreases supply of crops which consequently hinders commercialisation (FMARD, 2016).

\subsection{Post-independence framework of cocoa commercialisation - the marketing board}

Different policies and programmes have been put in place to solve the market failure of commodities and build a constituency for reform. The absence of a stable, efficient and predictable policy environment can hinder the growth of agricultural production, especially in the production of a cash crop like cocoa. Teal (2013) considered the history of cocoa production in the period after the Second World War as one characterised by heavy taxation. This pattern of taxing agricultural outputs to implicitly subsidise an urban growth of manufacturing was widespread across sub-Saharan Africa in the period following Nigerian independence and its failure to provide a basis for sustained growth was background to policies, which proved contentious (Teal, 2013). The British set up crop marketing boards in West Africa during the Second World War, motivated by commodity price and access concerns (Bauer and Yamey, 1968; Williams, 1985 p.15). The marketing boards were established to take over the export of crops from the Produce Control Board (Williams, 1985).
A marketing board is an organisation set up by a government to regulate the buying and selling of certain commodities within a specified area. In Nigeria, specifically, commodity marketing boards were established by the British in 1947. An example is the former Cocoa Marketing Board of Nigeria. After it was renamed as the Nigerian Cocoa Board (NCB) in 1977, the marketing of tea and coffee was also placed under its control. Such marketing boards are set up to stabilise producer prices, particularly in the case of products designed primarily for export markets in which price fluctuations are most violent. They are parastatal agencies with the monopoly for internal and external crop marketing (Cadoni, 2013). The first crop marketing board in tropical Africa was established in Zimbabwe (then Southern Rhodesia) in 1931, in response to pressure from European farmers for support of the export price of maize.

After the Second World War, the preservation of marketing boards was justified primarily on the ground of price stabilisation for chronically volatile world prices (Hubbard and Smith, 1996; Cullinan, 1999, p. 318). The impact of the marketing boards on these developing countries was substantial, and they sometimes came to be the wealthiest and most economically significant single unit in their respective economies (Bates, 2005). While their actions were justified in terms of price stabilisation, the marketing boards generally used their powers simply to siphon resources away from the agricultural sector (Williams, 2009). The activities of the marketing boards hardly benefitted producers, as they were used to perpetrate various interests and purposes. For instance, the marketing boards levied a tax on farmers, thus setting payments made to farmers for their produce substantially below world prices (Killick, 1990; Bates, 2005). The result of this was that it discouraged farm production and dampened farmers' income.

The demise of the marketing boards began in 1986, when SAP was announced along with the need to incorporate exchange rate liberalisation of export trade, reduction in extra budgetary expenditure, withdrawal of subsidies, and the privatisation of public enterprises. Thus, deregulation placed much emphasis on the market forces in determining the prices of goods and services and allocating resources within the economy. Therefore, the policy measures as they affect agriculture ensued as follows: (i) the abolition of the commodity board and the privatisation of many agricultural enterprises previously controlled by the government; (ii) market liberalisation and currency devaluation; and (iii) foreign exchange liberation and currency devaluation. 
Following the announcement of SAP, notable achievements were recorded in the cocoa industry. Akanji (1992, p. 79) recorded a drastic increase in cocoa production from 100,000t to 256,000t, and the lost glory of the cocoa industry was restored by 1993 when Nigeria recovered to become the fourth largest producer after Côte d'Ivoire, Brazil and Ghana. Conversely, cocoa production also declined again to as low as 170,000t in the year 2000 (CBN, 2004). Consequent to this decline, the Federal Government established the National Cocoa Development Committee (NCDC) in 1999, domiciled in the Federal Ministry of Agriculture and Rural Development. The NCDC has sub-committees on cocoa production, cocoa processing and value addition, increased consumption of cocoa products, and marketing. The sub-committees' establishment gradually improved cocoa production to 202,000t in 2004.

\subsection{Intricacies around the cocoa marketing board: the Nigerian experience}

Marketing boards in Nigeria found their justification in the view that the smallholder cocoa farmers were at the mercy of 'middlemen' and 'moneylenders', hence the need for the state to intervene to promote 'orderly marketing' (Williams, 1985, p. 11). Government officials and spokesmen for the European trading firms shared this perspective, despite all evidence that the boards were used to further selfish motives. While the boards were justified in terms of price stabilisation, the marketing board generally used their powers simply to siphon resources away from the agricultural sector (Williams, 2009). It has been argued that the marketing boards only succeeded to some extent in stabilising seasonal producers' prices, and achieved little success in stabilising producers' income because the profits that were supposed to accrue to Nigerian peasant producers were used by the colonial administration to cushion their industries abroad that were devastated during the Second World War.

The activities of the marketing boards hardly benefitted producers, as they were used to perpetrate various interests and purposes. For example, the marketing boards levied a tax on farmers, thus setting payments made to farmers for their produce substantially below world prices (Killick, 1990; Bates, 2005). This action subsequently discouraged farm production and dampened farmers' incomes.

The marketing boards also had a political undertone, as they were used by politicians to fulfil selfish motives. Williams (1985, p. 5) noted that Nigerian politicians found them a ready-made instrument for taxing farmers, enriching themselves and financing their political activities. The marketing boards became not only a means for collecting patronage resources, but also the vehicle for distributing them (Williams, 2009). Jobs within the agricultural marketing systems became rewards for party loyalty and the marketing boards soon became bloated, costly and under qualified as a result (Ayinde, 2014). Furthermore, there have been disputations that the colonial government policy was initiated in order to protect her imperial and economic interests at the expense of the Nigerian peasants, because the funds accumulated for years were used for purposes by the British and the Nigerian regional politicians other than those it was earlier put forward. Thus, marketing board system was a salient exploitative measure and oppression and maintains that the paltry infrastructural development and social amenities provided were largely accidental fallout of colonialism.

\subsection{Benefits of cocoa marketing board framework}

The marketing board era had positive impacts on cocoa production. As noted by Ayinde (2014), producers' price for cocoa tripled between the 1985 and 1986 harvests, as the NCB had prices close to world prices at the official exchange rate which gave farmers upturn returns on their investment.

Similarly, the prices of cocoa were more stable in the international market during the marketing board era than they became following its abolition (Ayinde, 2014). Ayinde further emphasises the need for government and cocoa farmers to learn from the price stabilisation mechanism of the marketing board era, without the exploitative factors of the scheme, to allow the farmers to experience and reap the benefit of higher output.

After the disbandment of the cocoa marketing board, certain important roles and functions were neglected. For example, the privatisation process neglected the transfer of important and positive roles being fulfilled by the state - such as quality control, input provision, extension, credit, and research and development - to private actors (Hubbard and Smith, 1996; Cullinan, 1999, p. 318; Shepherd and Farolfi, 1999; Daviron and Gibbon, 2002; ul Haque, 2004; Poulton et al., 2005). Quality concerns became especially pressing after liberalisation (AIDE, 1995; LMC, 1996; Shepherd and Farolfi, 1999). Without universal quality controls, private actors can exploit farmers by marketing a sub- standard cocoa product for the premium quality price. This creates a vicious downward circle in product quality, as the entry of sub-par products 
into the market erodes the origin's quality reputation and reduces the price premium for a produce. In turn, this diminishes the incentives for all parties to protect the quality of their products. The result can be quality collapse, which was the outcome of cocoa market liberalisation in Cameroon, Côte d'Ivoire and Nigeria (Varangis, Thigpen and Akiyama, 1990; de Jong and HartsBroekhuis, 1999; Fold, 2002).

Prior to the introduction of SAP in 1986, cocoa beans were exported by NCB. The NCB created and maintained a structure of Local Buying Agents (LBAs) for the sole aim of aggregating cocoa beans from farmers in the producing areas. The LBAs were responsible for transporting cocoa beans from farms, so that the farmers did not need to bother about transportation problems. But such is not the case anymore. A study conducted in Osun State, Nigeria shows that farmers prefer to sell their production to itinerant buyers because transportation costs are high due to their poor infrastructure condition. Moreover, uncertainties are attached to the grading of products as production can be rejected or the price reduced due to poor quality (Cadoni, 2013). As a result, producers prefer to avoid these two risks and sell their products to the intermediaries (Nkang, Ndifon and Odok, 2007, p. 458). 


\section{METHODS AND MATERIAL}

\subsection{The study area}

Nigeria is located on the western coast of Africa with diverse climatic features ranging from arid to humid equatorial. Abuja is the national capital, in the Federal Capital Territory created in 1976. Typical agricultural holdings are generally small and scattered; farming is often of the subsistence variety, characterised by simple tools which produce about 80 per cent of the total food. About 30.7 million ha (76 million acres), or 33 per cent of Nigeria's land area, are under cultivation (Chauvin, Mulangu and Porto, 2011). Nigeria's diverse climate, from the tropical areas of the coast to the arid zone of the north, make it possible to produce almost all agricultural products that can be grown in the tropical and semi-tropical areas of the world.

This wide range of both food and cash crops. The staple food crops include bananas, beans, cassava, coco-yams, corn, cow-peas, millet, plantains, rice, sorghum, sweet potatoes, yams, and a variety of fruits and vegetables. The leading cash crops are benniseed, citrus, cocoa, cotton, groundnuts (peanuts), palm kernel, palm oil and rubber. Agricultural products were the major exports in the 1960s and early 1970s until petroleum was discovered.

Cocoa is widely cultivated in the southern belt of Nigeria, owing to the soil and climatic conditions prevailing in the area. This includes Abia, Adamawa, Akwa-lbom, Cross River, Delta, Edo, Ekiti, Kogi, Kwara, Ogun, Ondo, Osun, Oyo, and Taraba. In terms of capacity, Ondo State is rated as the largest cocoaproducing state in Nigeria (Oluyole, 2018). Cocoa can be grown within a wide range of rainfall from $1,000-3,000 \mathrm{~mm}$ or more per annum. When irrigation is available and the occurrence of dry winds is limited, the crop can be grown completely without rain. Cocoa plants respond well to a relatively high temperature, with a maximum annual average of $30-32^{\circ} \mathrm{C}$ and a minimum average of $18-21^{\circ} \mathrm{C}$.

\subsection{Population of the study}

The population of the study comprised all producers, processors, marketers, input dealers, extension practitioners and researchers along the cocoa value chain in Nigeria.

\subsection{Research design}

The study adopted qualitative research design to collect information from all stakeholders in the cocoa value chain, which includes producers, processors, marketers, input dealers, extension practitioners and researchers. Ogun, Ondo and Osun states were purposively selected due to their historical relevance in Nigerian cocoa sub-sector. Four and three dominant cocoa-producing LGAs each were purposively selected from Ogun, Ondo and Osun states, respectively. Thereafter, two wards and three villages each were randomly selected from the sampled LGAs. FGDs, key informant interviews, and life story and diet diversity surveys were used as data collection methods. In this study, 32 FGDs, 25 IDIs and 15 life history interviews were conducted with famers, processors, input dealers and marketers in each state, while 20 diet diversity discussion sessions were conducted. The interview sessions were tape recorded and transcribed, and complemented with jotted notes. Life story interview sessions were used to elicit information from randomly selected farmers (three per generation) who began cocoa farming in the 1960s, 1970s, 1980s and 1990s. Data obtained were analysed using a qualitative thematic analysis. 


\section{RESULTS AND RESEARCH FINDINGS}

\subsection{Change in economy and livelihoods among Nigerian cocoa farmers}

Sequel to the setback suffered by most cocoa farmers since the millennium era the majority of farmers have shifted their focus to crops better to provide a reasonable income. Respondents across the different communities sampled during FGDs revealed that oil palm is the only crop that can compete with cocoa in terms of its high returns. For instance, discussants during an FGD in Ogbaaga, Osun state, Nigeria concluded that "going with the recent trend, oil palm has a better advantage in terms of less attention and expenses compared to cocoa production, which requires more attention and higher costs in weeding, fertiliser application, spraying of pesticides and is also faced with numerous pests, diseases, fake pesticides and marketing problems".

Further reports and observations generated during the study affirmed that there is a significant shift in the economy and livelihoods of cocoa farmers in the study area over the years. Cocoa farmers have now diversified into pig farming and oil palm processing as complementary sources of livelihoods to their cocoa production. Aside from being farmers, women are also involved in petty trading such as that of soya bean cake, while a number of men are artisans, retired civil servants and employees of private companies. Such activities help the respondents to maintain the adequate cash flow needed to maintain their cocoa farms and to also increase their economic portfolio. Discussants opined that the oil boom era attracted higher foreign exchange earnings from oil at the expense of cocoa production. Increasing urbanisation and prospects for less labour-intensive jobs led to rural-urban migration. As a result, the hectares cultivated by an average cocoa farmer in the post-oil boom era are smaller than in the pre-oil boom era. Generally, it was found that the cocoa farmers in the study area are mainly smallscale farm holders.

\subsection{Contributions of cocoa enterprise on farmers" income and poverty reduction}

Outcomes of various interviews conducted revealed that cocoa production have empowered some of the cocoa farmers to improve their housing from thatched roof-mud house to brick houses with aluminium roofs, while some have built houses in the city. Also, the proceeds from cocoa farming have helped them train some of their children with quality education. Some have been able to afford going to the holy land for pilgrimage. Some of the farmers met on the field could even afford more luxury lifestyle through the purchase

Plate 1: Oil palm processing plant in Aba Sango, Osun State Nigeria
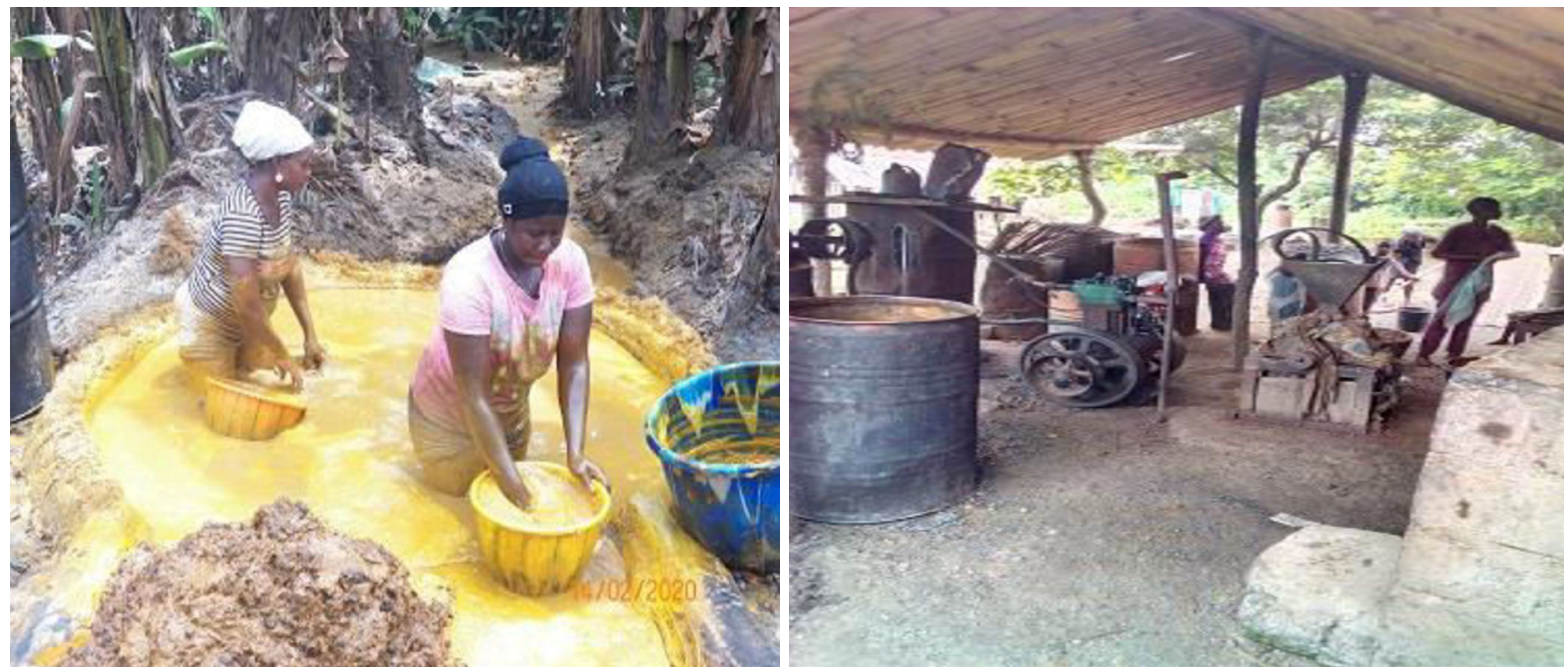

Source: Authors' own 
of mobile phones, cable TV, solar panel, television, motorcycles and motor vehicles.

"I have been able to give my children who want to study the education that I did not have, and this makes me happy. Also, when I was sick, and could not work for a long time, it was the proceeds from my cocoa farms that I depended on to pay for my treatment. If not because I cultivated cocoa when I was a young man, how would I have been able to achieve these things?" (IDI with Baale at Awotunde, Ogun state Nigeria).

This is contrary to Apata et al. (2010) and Okunmadewa et al. (2010), who submitted that poverty in Nigeria is especially severe among smallholder farmers who dwell in the rural areas with agriculture accounting for the highest incidence over the years (Edoumiekumo, Karimo and Tombofa, 2014). Despite characteristically low income, low or no access to production inputs, low productivity, illiteracy and lack of access to information and basic necessities of life, which describe these farmers as being poor, majority find a leverage to meet their basic needs from cocoa enterprise.

\subsection{Movement towards greater intensification among cocoa farmers in Nigeria}

The yield from cocoa production in the study area has dramatically reduced as a result of many factors. For example, the Baale of Oduja community and cocoa farmers attributed the decline in production to inadequate funds for farm maintenance and the high cost of labour. Other reasons include poor management of inherited cocoa farms and current disputes between government and communities over government land that has been encroached upon by residential and farming areas. At the time if this report, the government has issued orders to vacate the land, and threatened land seizures, to those residing on the disputed land, such as the Gbamugbamu and Olorunpodo communities in Ogun State. The people in Gbamugbamu and Olorunpodo expressed this situation as a significant challenge, because farmers' fear of losing their land should the government enforce their orders prevents them from expanding their cocoa production. In addition, the encroachers defend their actions, explaining there is no new land available for expansion, and that existing farm land is degraded in terms of fertility and productivity, thus there is no alternative than to move into the government reserves.

Lack of access to fertilisers, unfavourable climatic conditions, pest and disease infestations and poor infrastructural development - such as roads leading to communities and cocoa farms - have also been cited as contributors to the study area's decline in cocoa production. Tittonell and Giller (2013) asserted that in Africa, rising rural population density is responsible for rising land pressures, reduced fallows, more continuous cultivation and soil degradation. It is imperative, therefore, that relevant stakeholders pursue sustainable agricultural intensification, which includes investments in physical infrastructure, agricultural research and development and a policy environment supportive of private investment and competition in cocoa value chains.

\subsection{Push and pull factors for cocoa commercialisation in Nigeria}

Push factors that discourage engagement in cocoa farming, and commercialisation, reported in the study area include limited access to land, inadequate access to financial services, insufficient access to knowledge, information and education, poor employment opportunities for youth, limited access to markets and limited involvement in policy dialogue. Conversely, the pull factors that could encourage cocoa farming if properly harnessed by the government are; availability of legislated policy backing youth involvement, insurance policies, availability of markets, flexible land policies, cocoa farmers' inclusion in policy dialogues, adequate information and training on farm practices, financial support and access to farm inputs.

\subsection{Issues around Nigeria's cocoa enterprise}

\subsubsection{Land and labour situation in Nigeria's cocoa sub-sector}

Land is most critical among the factors of production. However, there is a slight variation in the land and labour relations across the cocoa-growing region of southwestern Nigeria. Among the cocoa-growing communities in Ogun State, both men and women have equal access to land for the purpose of cocoa cultivation either by inheritance, rent and lease or, in few instances, by purchase. Various community engagement methods deployed by the qualitative study team (FGDs, IDIs and life story interviews) across communities (including Ita-egba, Abeku, llumefon, Aratu, Dagbolu) confirmed this. However, in ljebu East LGA; J3 axis specifically, land is said to be leased from the Baale of the village who collects royalties (isakole) at the end of the farming year. With regards to gender disparities, women have equal access to land as men. This was further confirmed in Yewo community, under ljebu East LGA, as female FGD discussants posited those women have the freedom to own cocoa farms depending on their financial capacity. In ljebu North East axis, it was also confirmed that land inherited by 
families can be sold out or leased to migrant farmers which indicates that in Ogun State there is generally a good social relation within families, and in the community at large, on land access for cocoa farming.

Meanwhile, in Osun State, indigenes do not buy land. Rather, they inherit from their fore fathers. However, migrants typically attain land by lease or rent. They could also be given land, but hire friends who invited them to the community to do land clearing. The farmlands in the community are owned by specific compounds, 'agbole'.

Land access arrangements in Ondo State have equally experienced a lot of changes over time. Farmers' ancestral fathers, who were the first inhabitants of the land more than 400 years ago, acquired lands according to their different capabilities without any payment. Soon after those 400 years was when non-indigenes from Osun and Oyo came into the communities. For some cocoa-producing communities, land was given to nonindigenes and indigenes free of charge, while other communities required royalties (usually in cash and or kind) to be paid by non-indigenes. Subsequently, after this era, land acquisition was by purchase and lease at an affordable price.

Generally, due to the limited amount of civilisation and urbanisation lands for agriculture, non-indigenes who got their lands by lease now lament that they have lost their farmlands to community development (construction of roads and building of houses). Farmlands are also sold by landowners to people for building houses without prior notice to farmers (non-indigenes and indigenes) and with little or no compensation. Discussions from the men and women focus groups also revealed that farmers who lose their land usually have to accept such occurrence as fate and reasons outside anyone's control to avoid conflict with the landowner, because of the fear of losing the remaining lands. This implies that security of land for continuous production is no longer guaranteed in the study area.

Labour is also extremely important on smallholder farms. Information gathered in the study area reflected that in the past, there was a sufficient labour force for cocoa farm activities because farmers commonly engage in polygamy in order to have large families who can serve as labourers for farming operations. However, there have been a lot of changes in labour availability over time, because farmers no longer have money to marry multiple wives, children no longer follow their parents to work on farms, and only the rich farmers can afford the available labourers. During one of the FGDs with men, a farmer reiterated that "in the past, labourers literally came from different communities within and outside the community to beg to be hired as labourers in the community, but it is unfortunate that they are no longer easy to come by." In Ondo State, farmers pointed out the issue of deception and their suspicion resulting from the challenges they face in their bids to get labour. For example, they cited instances of labourers demanding advanced payment of their labour charges, and subsequently refusing to come on time or not even show up.

Another recent development in labour acquisition in the study area is the hiring of labour on a contractual basis. In this arrangement, farmers who need labour do not necessarily have to go through the stress of searching for a reliable labourer, but can operate through labourcontracting agencies. Payment is made directly to the labour vendor before labourers are hired, which is cited as a contributing factor to the high cost of labour. On methods of remuneration, yearly labourers, which are most commonly used, are paid at the end of the year in cash, though in some cases labourers can demand a motorcycle in lieu of cash payment. Other means of remuneration include the calculation of their payment as a share of the cocoa farm's total profit, for example, the labourer will receive one-third of the farm's profit, while two-third goes to the farm owner. Daily labourers, otherwise known as 'caretakers', are commonly used by women farmers due to labour intensity associated with daily activities in cocoa operations. They are paid based on an agreed amount, typically £1.92 for men and £1.53 for women labourers' par day. Discussants affirmed that, on average, a smallholder cocoa farmer

Table 4.1: Activities carried out by women and children in cocoa enterprises

\begin{tabular}{|l|l|}
\hline Role of women & Role of children \\
\hline Preparing of food for family and labourers & Collection of harvested pods \\
\hline Fetching of water during spraying operation & Depodding of cocoa beans \\
\hline Collection of harvested pods & Drying of cocoa beans \\
\hline Depodding of cocoa beans & \\
\hline Fermenting and drying of cocoa beans & \\
\hline Bagging of dried cocoa beans & \\
\hline
\end{tabular}

Source: Authors' own 
will spend approximately $£ 153.84$ on labour per year, while farmers with larger farms might spend a minimum of £320.51. Incidences of family labour, particularly child labour, is prominent in many cocoa-growing regions, simply because of the high cost of paid labour (KPMG, 2013). Some of the activities carried out by women and children in the family cocoa enterprise are tabulated in Table 4.1.

\subsubsection{Herdsmen devastation in cocoa growing communities}

Information obtained during the interviews established incidences of herdsmen attacks on cocoa farms in southwestern Nigeria. One of the discussants in Ayetoro community in Ogun State said "herdsmen now invade our farms to feed cocoa beans to their cattle. All efforts to tame them have proved abortive, simply because they carry guns." This story is the same in Osun and Ondo States. As such, many farmers are now afraid to go to farms and the commitment and enthusiasm of farmers to expand their farmlands is currently under threat.

\subsubsection{Poor quality of cocoa beans - a fallout from cocoa board cancellation}

The yields from cocoa production have not only drastically reduced, but the quality of cocoa beans produced is below the recommended standard for export. During the interactive sessions conducted in the cocoa-farming communities in Ondo State, for example, a purchasing clerk in Ondo West LGA, highlighted that, "most farmers don't allow the beans to ferment for a minimum of the required five days - all they are concerned with is how it will get dried to an extent so that it can be sold for them to get their money."

The purchasing clerk added that during the operation of the cocoa board in the country, cocoa quality had three different grades (A, B, C) and each grade was bought at different prices. For example, Grade A would command a higher price than B and C. As a result, farmers paid more attention to taking care of the beans right from when they were still on the tree. The field supervisor, Tulip Processing Company also lamented, "we now get a higher per cent of moulds in cocoa beans produced, which sometimes we buy due shortages in cocoa production." A local buying agent interviewed in Laje community, Ondo West LGA also shed more light on the issue, explaining that, "there are more buyers than producers in the cocoa industry now than before, which is responsible for the variation in prices and the production of beans below the standard quality".

\subsubsection{State of technology support in cocoa commercialisation in Nigeria}

The study reveals that farmers have little or no exposure to the latest technology in cocoa production. The FGD conducted across all the communities showed that the old method of cocoa production is still been used to date. However, in recent times, it was expressed by one of the discussants during an FGD that they received training from Olam, a private sector company, on improved cocoa production, and were provided solar dryers, Terranga, a technology used to dry cocoa and remove foreign materials (contaminated objects) from the seeds, and personal protective equipment to prevent exposure to pesticides during cocoa spraying. According to discussants, Olam has also provided nose cover during the recent COVID-19 pandemic.

\subsubsection{Government support towards cocoa commercialisation in Nigeria}

The majority of the farmers in different communities

Plate 2: Untarred slippery road in Gbonawa community, Ondo State
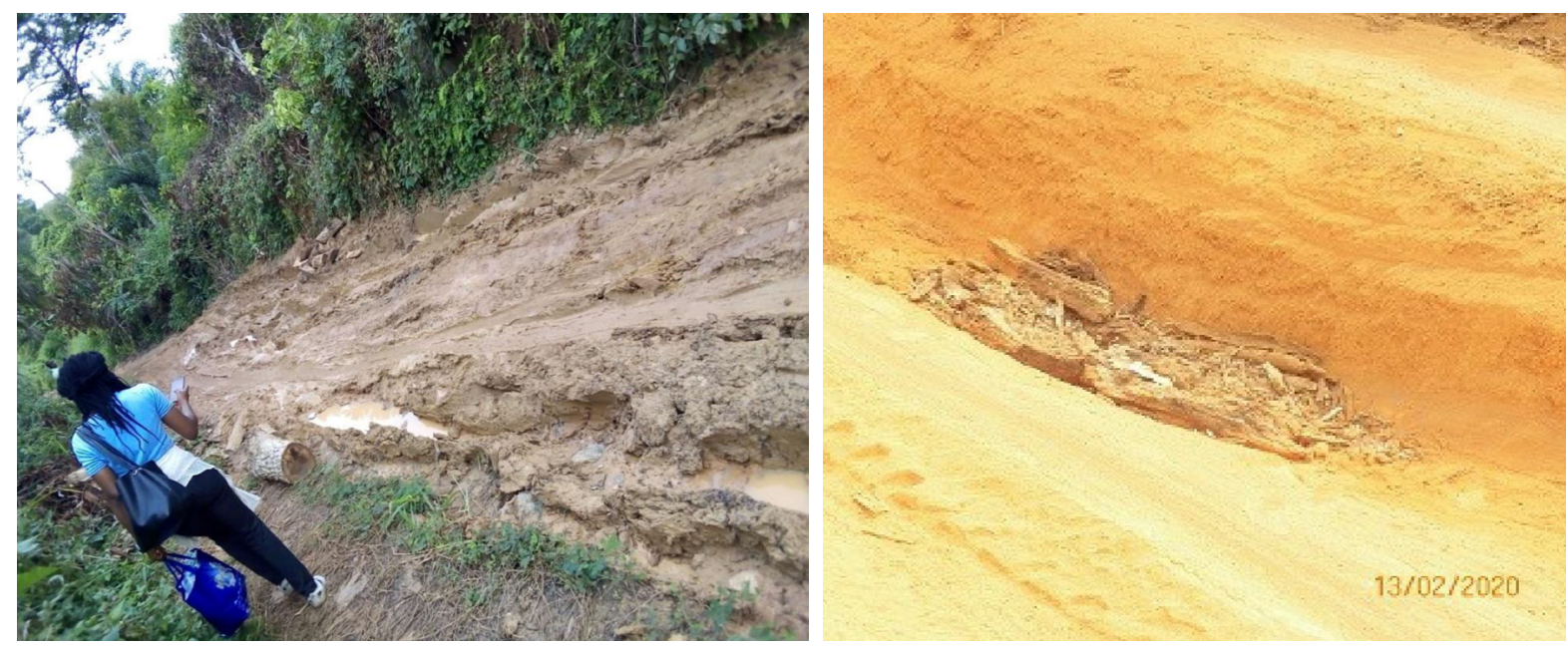

Source: Authors' own 
during the discussion sessions reported that the government seems not to recognise nor care about the farmers. The reasons for this perception included:

- $\quad$ They haven't received any public assistance for a long time;

- $\quad$ There are no funds to finance their farms;

- $\quad$ Farmers have tried to organise groups to receive assistance but the government seems to turn down the efforts.

The only interventions the farmers recall was the supply of cocoa seedlings in 1973, which farmers referred to as 'cocoa agric'. For instance, in Ogun State, farmers claimed that, in recent times, government-supplied farm inputs do not reach them. Instead, as expressed during the FGD session in Oduja community, those who claim to be government officials defraud them. The participants have also claimed that, in Ita-Egba community, the government has sometimes destroyed cocoa farms without compensation in the cases of those who had encroached into government reserve areas. In contrast, women in Olorunpodo community noted that they have recently received intervention from the government in collaboration with the government's anchor borrowers' scheme through the Cocoa Farmers' Association of Nigeria (CFAN). Hence, some farmers who are members of CFAN received chemicals and funding support, while non-members did not.

\subsubsection{Infrastructural support}

In nearly all the cocoa-growing communities studied, physical infrastructure was in a deplorable state. Bad road networks were characterised with bad topography, thus preventing farmers from having easy access to markets and other benefits those closer to urban areas enjoy. The Baale of Gbonawa community in Ondo State complained that, "this situation also usually prevents buyers from coming to buy their produce because of the cost of transportation, at the long run reduce farmers' bargaining power, and so produce is sold at ridiculous amounts to purchasing clerk willing to buy." In addition, in most of these communities, communication networks, electricity and health facilities are hard to come by. These features trigger migration among youth out of the study areas to search for a better life elsewhere.

\subsubsection{Financial support}

Most discussants claimed that there has been no financial support from the government for decades. However, some attest that farmers who registered with the Farmers Development Union get benefits from the government. Further probes revealed that in
Ondo State, cocoa farmers in the past have enjoyed soft loans from the government through African Development Banks, which no longer exist. Soon after the closure of the African Development Banks, cocoa farmers began to borrow money from LBAs for farm expansion, farm maintenance and to meet urgent family needs. These LBAs usually deduct the advances from the amount for which they agree to sell their produce. However, some LBAs decided to stop this practice due to the untrustworthy attitude of some farmers, citing instances in which they lost money to farmers who came for their assistance.

An example of such an act was shared by a UTZcertified LBA in Ajue community, Odigbo LGA of Ondo State, who lamented, "I have a fair share of farmers' disloyalty and I now lend money to only the few farmers I know will not betray my trust". Another buyer who started buying cocoa in 1991, affirmed this reality saying that "farmers are dishonest, as they do not sell their cocoa to the buyers who lent them money and/ or chemicals."

Other sources of finance shared during the interviews include: loans from Lapo, a microfinance bank with high interest rates, cooperative groups, pensions from previous government employment, petty trades, and friends and family. The implication of this backdrop is that farmers do not have a stable source of finance for the expansion of their cocoa businesses, hence, may not be able to adequately manage the existing cocoa farms which will lead to a continuous decline in production and cause serious setbacks in cocoa commercialisation.

\subsubsection{Extension service support}

Cocoa farmers face various obstacles in their efforts to increase production and farm income. It is imperative, therefore, for extension officer to pay regular visits to farms in order to facilitate adoption of the knowledge and skills required to overcome such obstacles. Unfortunately, interviews conducted show that extension officers rarely visit cocoa farms, unlike in the past when visits were more regular. Cocoa farming in southwest Nigeria is traditionally managed with limited financial capital and farmers' level of knowledge and skills, especially in the aspect of improving the quality and competitiveness of cocoa products. In addition, farmers face challenges outside the production process, especially those concerning the difficulty of access to capital, marketing and distribution of products, as well as stability and price standardisation.

Conversely, farmers attested to the fact that they have previously enjoyed extension support in the form of provision of improved varieties of cocoa seedlings, 
training programmes, field demonstrations and more, through the Cocoa Development Unit, Agricultural Development Programme, and FADAMA projects, as well as other non-governmental organisations including SARO, Stanmark and Tulip Processing Companies. However, there were complaints that both governmental and non-governmental organisations have not been able to fulfil the promised financial support.

\subsection{Nigeria's cocoa enterprise from a futuristic view}

\subsubsection{The future of the cocoa enterprise from farmers' perspectives}

Cocoa farming has a promising future as posited by FGD discussants across southwest Nigeria, but there are hurdles that must be overcome if this potential will be adequately explored. The greatest among these challenges is land availability and access. As gathered from IDIs with stakeholders in the sector, the government is gradually shifting its focus from oil and gas to revisit agricultural production in Nigeria. Thus, if the government can give more attention to reinvesting in cocoa production, the lost glory of cocoa can be revived and the future will be redeemed. Conversely, a few informants felt that the future of cocoa is uncertain as a result of the numerous constraints the industry is currently facing. For example, production is drastically reducing, the majority of the farmers are diversifying into cultivating other crops - such as banana, cocoa yam, oil palm, plantain and yam - as well as other livelihood activities like lumbering and small-scale businesses.

\subsubsection{Cocoa processing in Nigeria: How do we fare?}

Cocoa processing in southwestern Nigeria leaves much to be desired. The culture of direct sales of cocoa bean is still predominant in the study area. Ondo State has the largest presence of cocoa processing factories of the states in the southwest, which include Cocoa Products (IleOluji) Limited, a subsidiary of the Ondo State government. Other factories include Olam Coop Cocoa Factory, the cocoa processing division of Olam Nigeria Limited which is involved in processing and supplying a wide range of cocoa products; Plantation Industries Limited, an Akurebased cocoa processing factory that processes cocoa beans into a range of cocoa products such as cocoa butter, cocoa powder, cocoa liquor and cocoa cake; the Centre for Cocoa Development Initiative, which was established to promote and improve the development of cocoa production and processing in Nigeria and its health benefits; and Stanmark Cocoa Processing Company Limited, a farm that deals in cocoa processing and exportation.
In Ogun State, Olam and Tulip Cocoa Processing Limited are the most prominent cocoa processors. Osun State has only Ede Cocoa factory, which, according to farmers, was not functional at the time of information gathering. To say the least, processing as a component of value chain development in the study area is not faring well. Throughout the years of cocoa production in Nigeria, many of the processing plants have been foreign companies, while indigenous companies typically operate for a while and then close.

\subsubsection{Gender and generational roles for sustainable cocoa production in Nigeria}

The involvement of youth and women in cocoa production has reduced over time in the study area. Discussants affirmed that family labour was predominant in the past, because farmers generally had larger families in which their wives and children were used as labourers. Farmers reported that nowadays, parent disallow their children from following them to the farm, leaving only their wife, or wives, to assist them on the farm when they are not engaged with other business activities.

Women's roles mainly include: gathering of harvested cocoa pods, extracting of beans from pods, and drying of cocoa beans. However, there seems to be an exception to the above-mentioned roles, especially for farming households headed by women. In such situations, women have to carry out more tasks like plucking cocoa pods from trees, spraying chemicals and selling the produce. This was affirmed by the responses given by some adult women during an FGD at Orititi community at ljebu Northeast and another FGD with young women at Gbamu-Gbamu community, ljebu East, LGAs.

The rewards women received for assisting their husbands on the cocoa farms vary depending on location. In some communities, especially ljebu North (ljebu lgbo) LGA, women get tangible rewards such as money, while some women claimed they also get compensation in the form of gifts (clothes, shoes, bags, etc.) from their husbands during festive periods. Many often receive money from their husband for the expansion of their own businesses (usually petty trade), and others receive their own compensation from other produce on their husbands' farms such as Kolanut and oil palm. The men often make palm oil and gaari from cassava to sell, and such earnings belong to their wives. A contrasting trend was reported in Osun and Ondo States. Women are not given any form of cash reward for working for the husband. They believed that monetary reward was not necessary in as much as their husbands are responsible for their basic needs in the home, which include paying children school fees, 
food and other family welfare costs. Culturally, men make major decisions in the household even on things that affect the women. Although, some claimed that women can provide opinions during the deliberations despite the fact that the man of the house still has the final say. 


\section{GONCLUSION AND RECOMMENDATIONS}

Despite the setback in the development of Nigeria's agricultural sector, and its cocoa production, witnessed in the recent years, the potential to regain the country's former production capacities still abounds. The challenges facing the cocoa sub-sector, such as weak land-labour relations, infrastructure, and financial and extension support across the southwest, have all been partly responsible for the poor intensification of cocoa commercialisation in Nigeria. In addition, the poor quality of cocoa beans resulting from the cocoa board's dissolution has contributed to the low price of cocoa in both the local and international markets, and opportunities for cocoa intensification are crippled by insufficient funding, labour shortages and poor management practices. However, these obstacles have created a window for a significant shift in the economy and livelihoods of cocoa farmers in the study area over the years. There is no doubt that cocoa production has empowered some cocoa farmers to improve their standard of living, as the study affirmed that cocoa production has substantially contributed to farmers' income and poverty reduction. Therefore, it becomes imperative for relevant stakeholders to inject deliberate and sustainable interventions into the Nigerian cocoa sector in order to reduce out-migration and price instability, and encourage value chain development so as to secure the uncertain future of cocoa in Nigeria and improve the livelihood outcomes for those engaged in this sector. 
AIDE (1995). Memoire on the liberalisation of the cocoa sector, presented to the World Bank during the mission of the ICCO to Washington, pp. 6-8.

Akanji, B. (1992) Cocoa Marketing under Nigeria's structural adjustment programme. Ibadan: Nigeria Institute of Social and Economic Research.

Apata, T., Apata, O., Igbalajobi, O. and Awoniyi, S.M.O. (2010) 'Determinants of rural poverty in Nigeria: evidence from small holder farmers in south-western, Nigeria', Journal of Science and Technology Education Research 1(4): 85-91.

Bates, R.O. (2005) Markets and States in Tropical Africa: The political basis of agricultural policies. Berkeley: University of California Press.

Bauer, P.T. and Yamey, B.S. (1968) Markets, market control, and marketing reform. Letchworth: Garden City Press.

Berry, S. (1975) Cocoa, custom, and socio-economic change in rural Western Nigeria. Oxford: Clarendon Press.

Cadoni, P. (2013) Analysis of incentives and disincentives for cocoa in Nigeria. Monitoring African Food and Agricultural Policies Technical Notes Series. Rome: Food and Agriculture Organization of the United Nations (FAO). Available at: https://www.fao.org/3/at586e/at586e.pdf (Accessed:24 August 2021.

CBN (2004). Central Bank of Nigeria Annual Report and Statement of Accounts, Central Bank of Nigeria, Abuja, Nigeria.

Chauvin, N.D., Mulangu, F. and Porto, G (2011) Food Production and Consumption Trends in Sub-Saharan Africa: Prospects for the Transformation of the Agricultural Sector. Working Paper 2011-011. New York: United Nations Development Program.

Cullinan, C. (1999) Law and markets: Improving the legal environment for agricultural marketing, FAO Agricultural Services Bulletin 139. Rome: Food and Agriculture Organization of the United Nations (FAO). Available at: https:// www.fao.org/sustainable-food-value-chains/library/details/en/c/267222/ (Accessed: September 302021.

Edoumiekumo, S.G., Karimo, T.M. and Tombofa, S.T. (2014) 'Income Poverty in Nigeria: Incidence, Gap, Severity and Correlates', American Journal of Humanities and Social Sciences 2(1): 1-9.

FAOSTAT (Food and Agricultural Organization of United Nations) (2018) Available at: http://www.fao.org/faostat/ en/\#data (Accessed: 12 March 2021).

FMA (1984). Information Bulletin on Nigerian Agriculture. Federal Ministry of Agriculture Publications. Lagos, 1984.

FMA (1989) Agricultural policy for Nigeria. Federal Ministry of Agriculture water Resources and Rural Development, Lagos Reprint.

FMARD (Federal Ministry of Agriculture and Rural Development) (2016). The Agriculture Promotion Policy (2016 2020) Building on the Successes of the ATA, Closing Key Gaps. Available at: http://fscluster.org/sites/default/files/ documents/2016-nigeriaagric-sector-policy-roadmap_june-15-2016_final1.pdf (Accessed: July 42021.

Hubbard, M.I. and Smith, M. (1996) Agricultural marketing sector review. The Role of Government in Adjusting Economies. Paper 6, Birmingham: University of Birmingham Development Administration Group. 
Ibrahim, H.K. (2016) 'Economic Effect of Commercialization of Cereal Production in Kwara State, Nigeria', NiuginiAgrisaiens, 8(1): 7-17. Available at: http://www.unitech.ac.pg/sites/default/files/Volume\%208-2016.pdf (Accessed: 10 April 2021).

Killick, T. (1990) Markets and Governments in agricultural and industrial adjustment. ODI Working Paper 34, London: ODI.

KPMG Advisory N.V. (2013) Moving the bars: Sustainability brought to the forefront in the cocoa chain. 2013. The Netherlands: KPMG Advisory N.V. Available at: http://www.cocoaconnect.org/sites/default/files/publication/ kpmg_evaluation_cip_web.pdf (Accessed: 29 March 2021).

LMC International (1996). Final Report: The external marketing of Ghana's cocoa, prepared for the ministry of finance on behalf of the government of Ghana.

Nkang, N.M., Ndifon, H.M. and Odok, G.N. (2007) 'Price Transmission and Integration of cocoa and Palm Oil Markets in Cross River State, Nigeria: Implications for Rural Development', Agricultural Journal 2(4): 457-463.

Okunmadewa, F., Olaniyan, O., Yusuf., S.A., Bankole, A.S., Oyeranti, O.A., Omonona, B.T. and Olayiwola, K. (2010) 'Poverty and Inequality among Rural Households in Nigeria' in: F.O. Ogwumike (ed.), Poverty and Inequality in Nigeria. " African Economic Research Consortium (AERC) Nairobi, Kenya and Joycefitround Publishers,40,Oba Olagbegi Neighbourhood, Osuntokun, Old Bodija, Ibadan,2010, Pp 37-77.

Oluyole, K.A. (2018) 'Competitiveness and Comparative Advantage of Cocoa Production in Southwestern: A Policy Analysis Approach', Universal Journal of Agricultural Research 6(2): 57-61.

Poulton, C., Gibbon, P., Hanyani-Mlambo, B., Kydd, J., Wilbard M., Larsen, M., Osorio, A., Tschirley, D., and Zulu, B. (2005). Competition and coordination in liberalized African cotton market systems', in Frank Ellis and H. Freeman (eds), Rural livelihoods and poverty reduction, Routledge: pp. 166-182 Research Report, Oxford: Oxford University Press.

PwC (PricewaterhouseCoopers Limited) (2016) Transforming Nigeria's Agricultural Value Chain: A case study of Cocoa and Dairy Industries. Nigeria: PwC.

Shepherd, A. and Farolfi, S. (1999). Export crop liberalisation in Africa: A Review, FAO Agricultural Services Bulletin 135, Rome: Food and Agriculture Organization (FAO).

Teal, F. (2013) Agricultural revolution in Ghana. Paper presented at the Centre for the Study of African Economies Conference: Economic Development in Africa,, Oxford, 17-19 March 2013.

Tittonell, P. and Giller, K. (2013) 'When Yield Gaps Are Poverty Traps: The Paradigm of Ecological Intensification in African Smallholder Agriculture', Field Crops Research 143: 76-90.

ul Haque, I. (2004). 'Commodities under neoliberalism: The case of cocoa', G-24 Discussion Paper Series 25, Geneva: United Nations Conference on Trade and Development (UNCTAD).

Verter, N. and Bečváŕová, V. (2014) 'Analysis of Some Drivers of Cocoa Export in Nigeria in the Era of Trade Liberalization', Economics \& Informatics 6(4): 208-218.

Walker, E.A. (1999) The Rise and Decline of Cocoa Production in Southwestern Nigeria from 1900 TO 1993. Unpublished PhD Dissertation submitted to Michigan State University.

Williams, G. (1985) 'Marketing without and with marketing boards: the origins of state marketing boards in Nigeria', Review of African Political Economy, 12 (34): 4-15.

Williams, T. (2009) An Africa success story: Ghana's Cocoa marketing system. IDS Working Paper Series 318. Brighton: Institute of Development of Studies. Available at: https://opendocs.ids.ac.uk/opendocs/ handle/20.500.12413/4176 (Accessed: 18 March 2021).

Woldeyohanes, B.T., Heckelei, T. and Surry, Y. (2015) 'Effect of Off-farm Income on Smallholder Commercialization: Panel Evidence from Rural Households in Ethiopia'. A paper presented at the 29th International Conference of Agricultural Economics (ICAE), Millan, Italy. Available at: https://ageconsearch.umn.edu/bitstream/211895/2/ WoldeyohanesEffect\%20of\%20offfarm\%20income\%20on\%20smallholder\%20commercialization65.pdf (Accessed: 4 March 2021). 
Thomas, K.A., Oladjide, A. and Olutayo, M.O. (2022) Cocoa Commercialisation in Nigeria: Issues and Prospects. APRA Working Paper 79. Brighton: Future Agricultures Consortium.

(c) APRA 2022

ISBN: 978-1-78118-905-4

DOI: $10.19088 / A P R A .2022 .001$

\section{(cc) BY-NC-ND}

This is an Open Access report distributed under the terms of the Attribution-Non Commercial-No Derivs 4.0 Unported (CC BY-NC-ND 4.0) Attribution - You must give appropriate credit, provide a link to the license, and indicate if changes were made. You may do so in any reasonable manner, but not in any way that suggests the licensor endorses you or your use. NonCommercial — You may not use the material for commercial purposes. NoDerivatives - If you remix, transform, or build upon the material, you may not distribute the modified material. You are free to: Share - copy and redistribute the material in any medium or format.

https://creativecommons.org/licenses/by-nc-nd/4.0/legalcode

If you use the work, we ask that you reference the APRA website (www.future-agricultures.org/apra/) and send a copy of the work or a link to its use online to the following address for our archive: APRA, Future Agricultures Consortium, University of Sussex, Brighton BN1 9RE, UK (apra@ids.ac.uk)

All APRA Working Papers go through a review process before publication.

\section{@creative}

\section{DO YOU HAVE COMMENTS ON THIS PAPER?}

We would welcome your feedback on this working paper!

To provide brief comments, please follow this link to our short APRA Working Paper Feedback form: https://goo.gl/forms/1iVnXhhrlGesfR9

Agricultural Policy Research in Africa (APRA) is a programme of the Future Agricultures Consortium (FAC) which is

generating new evidence and policy-relevant insights on more inclusive pathways to agricultural commercialisation in sub-Saharan Africa. APRA is funded with UK aid from the UK Foreign, Commonwealth \&

Development Office (FCDO) and will run from 2016-2022.

The APRA Directorate is based at the Institute of Development Studies (IDS), UK (www.ids.ac.uk), with regional hubs at the Centre for African Bio-Entrepreneurship (CABE), Kenya, the Institute for Poverty, Land and Agrarian Studies (PLAAS), South Africa, and the University of Ghana, Legon. It builds on more than a decade of research and policy engagement work by the Future Agricultures Consortium (www.future-agricultures.org) and involves more than 100 researchers and communications professionals in Africa, UK, Sweden and USA. 